\title{
The Royal Academy.
}

E VERY critic of the Royal Academy finds material for praise or for condemnation from whatever point of view he regards the works exhibited, and the scientific visitor is no exception to this rule. Indeed, it is impossible that among so large a number of works all should be of the same high order of merit as are the few produced by master hands. From the scientific point of view it is not difficult to divide the sheep from the goats-the true representations of Nature from the grotesquely unreal. It may be presumed that the perpetrators of the latter type of work visit the Academy and there study the pictures of their fellow-artists. If this be so, it is astonishing that they should continue from year to year to produce unreal caricatures of natural objects, when often in close contiguity to their pictures are to be seen beautiful representations of the same type of scenes, truthful to life in every particular, and gaining immeasurably thereby. The fact that both obtain admittance to Burlington House must be taken to demonstrate that both are of artistic merit, but there the similarity ends.

An example of this contrast in methods of dealing with a subject may be found in this year's exhibition by comparing "Off the Land" (38) with "Sunset at Sea" (347). Both show sea and sky scenes. The former gives a perfectly natural representation of light from the sky reflected in the sea, while in the latter an intensely red sunset sky meets at the horizon an intensely blue sea, a condition unlikely to obtain while water possesses its normal powers of reflection. The effect is so entirely unnatural that it is difficult to believe, without reference to the title, that the lower part of the picture is meant to represent water at all. In Gallery No. III., on either side of the chief centre piece, with which the scientific critic is not concerned, are two pictures of yacht racing which form an interesting contrast. When looked at from near-by the one is wholly delightful, while the other is spoilt by its crude sky. When, however, a view is taken from a considerable distance, the two pictures appear of more equal merit. The contrast between the two methods of treatment is brought out strikingly by the juxtaposition of the pictures, be it accidental or otherwise.

A feature of the present exhibition which will strike the visitor is the extraordinary sea-colouring in several of the works, though examination of the catalogue shows that for this a single artist is largely responsible. One case has already been cited. To mention one other from among several examples, it would be very surprising to meet in Nature with the contrasts in colouring depicted in "The Sunken Reef" (I77). The writer has not had any opportunity of studying dazzle-painted ships in their natural surroundings, but if in the work "In the Narrow Seas" (200) Mr. Norman Wilkinson has given a correct representation of the effect produced-and there seems no reason to doubt that this is the case-it is well brought home to the landsman how baffling the effect must have been to the commanders of enemy submarines. In "The Forerunner" Leonardo da Vinci is seen showing a model of his flying machine to Ludovico Sforza, Duke of Milan, and his Court. Some of the spectators look amused, and for this the modern airman will find little difficulty in forgiving them. Several of Leader's beautiful scenes are exhibited. In studying "An Autumn Evening" (139) one wonders what object outside the picture casts a shadow over the lower part of the trees, while the upper part is illuminated with an evening glow; but there is no temptation to doubt the truthfulness of the portrayal.

J. S. D.

\section{Obituary.}

\section{Capt. E. W. Creak, C.B., F.R.S.}

CAPT. ETTRICK WILLIAM CREAK, who died in his sleep on April 3, was the son of the late Commander William Creak, of Norfolk, and a nephew of Sir H. Havelock, of Lucknow fame. He joined the Navy in the navigating branch of that Service about the year 1849 , and served in various ships afloat until he was selected in 1868 to serve as an assistant in the compass department of the Admiralty. His service afloat was distinguished not only by his nautical acquirements and the remarks he sent from time to time to the Hydrographer, for which he was specially thanked in 1866 , but also by his knowledge of French and music, rather rare acquirements in those days. He was able to add to our knowledge of some unsurveyed NO. 2636 , VOL. IO5] localities by his study of surveying operations, particularly by a plan of Ngaloa Bay, in the Fiji Islands, when serving in H.M.S. Esk about 1866. About this time Capt. Creak turned his attention to the errors of the compass on board certain ships which had traversed a great range of magnetic latitude, which inquiry was embodied in a report to the Admiralty and published by the Board of Trade. This marked him out as a suitable officer to be employed in the investigation of compass errors in H.M. ships, which were being increasingly constructed of iron and steel. For his services in the compass department and his magnetic reports he was made a fellow of the Royal Society in 1885 , and he became superintendent of the Admiralty compass department in 1887.

Capt. Creak took an active part in the determination and control of the constants required for 
the reduction of the magnetic observations made by the Challenger expedition, $1872-76$, during which expedition it was discovered that the coral islands of Bermuda lay over a magnetic field in which the variation of the compass differed as much as $6^{\circ}$, viz. from $4^{\circ} \mathrm{W}$. to nearly $10^{\circ} \mathrm{W}$., the true variation of the needle being $7^{\circ} \mathrm{W}$. ; this was ascertained by swinging the Challenger on every point in deep water close to the islands, and this process was continued on board that vessel in many other parts of the world, where the true variation was affected by local attraction on shore, so that the results of the shore observations were not trustworthy; but the Challenger being a wooden vessel, although not entirely free from iron in her construction, better results were obtained by swinging her in deep water near the land. The results of the Challenger observations are published in vol. ii. of the official narration of the voyage, and in vol. ii. of the reports on the physics and chemistry of the expedition, where plans, constructed by Creak, are given of the magnetism observed at the Bermuda Islands, and also charts of the variation, inclination, horizontal force, and vertical force for the epoch 1880 , constructed mainly from the Challenger observations, combined with all other observations available to the date of publication.

Capt. Creak pointed out in his magnetic contributions that at certain positions in the world magnetic shoals exist which affect the compasses of vessels sailing over those shoals. One such shoal near Cossack, in North Australia, was crossed by H.M. surveying vessel Meda, in a depth of 8 fathoms, with two shore objects transit, and the compass needle was deflected $30^{\circ}$ for about one mile.

At Funafuti, another coral atoll in the Pacific, in lat. $8^{\circ} 3 \mathrm{O}^{\prime} \mathrm{S}$., long. $179^{\circ} \mathrm{r} 2^{\prime} \mathrm{E}$., another magnetic field exists, where the variation changes nearly $2^{\circ}$, and the $\operatorname{dip} \mathrm{I}^{\circ}$, in different localities, as shown by the magnetic survey of the atoll made by Admiral Sir A. Mostyn Field in H.M.S. Penguin in 1896 , the results being investigated by Capt. Creak, and published by the Royal Society in 1904. Capt. Creak also instructed the officers engaged in the Arctic expedition of $1875-76$ under Capt. G. S. Nares, R.N., and prepared the directions and magnetic charts for the "Arctic Manual," I875. He also prepared the magnetic instructions for the Antarctic expedition of rgor. When, owing to his having reached the age of fifty-five, he had to retire from active service afloat in 1890 , and to his not having served the number of years afloat to entitle him to be retired with the rank of captain, a special Order in Council was issued giving him that rank, so that his important services in the compass department should not deprive him of the honour he would have received had he served the requisite number of years at sea.

During Capt. Creak's service in the compass department the late Lord Kelvin invented a compass superior to that then in use in H.M. NO. 2636 , VOL. IO5] ships, which was adopted by the Admiralty; but, owing to the increase in the size of the guns in H.M. ships, this compass was eventually discarded for a liquid compass brought out by Capt. Creak, which is now the standard instrument afloat, and is furnished with a special azimuth circle for use in torpedo-boats, destroyers, etc., all other compasses having failed to stand the vibration and motion and the gunfire in these vessels. $\mathrm{He}$ also brought out a simple form of instrument for correcting by magnets the heeling errors, and invented the Lloyd-Creak dip and intensity apparatus, originally meant for observations afloat, but which has been found very useful also on shore. This instrument was fully described in Terrestrial Magnetism for October, Igor.

In r9o3 Capt. Creak was president of the geographical section of the British Association, and in his presidential address at Southport in that year gave an interesting account of the progress of our knowledge of magnetism both afloat and ashore up to that time, which was published in the Proceedings of the British Association, and also in the Geographicai Journal, vol. xxii., 1903. He was made a C.B. in I9or, in which year he was retired from the compass department at the age of sixty-six. Capt. Creak also assisted the late Sir Frederick Evans and Mr. Archibald Smith in preparing and publishing the "Elementary Manual for the Deviations of the Compass in Iron Ships" in 1870 , and after the death of Sir F. Evans later editions of that manual were entirely prepared and published by Capt. Creak. In the ninth edition prepared by him in 1895 the question of heeling error and its correction was specially discussed, and tables were given to assist in the correction of quadrantal deviation and the application of the Flinders bar, etc.

T. H. T.

\section{Sir Edmund Giles Loder, Bart.}

THE death of Sir Edmund Loder at the age of seventy removes from the ranks of English country gentlemen one of the cultivated members of that class. Possessed of ample means and abundant leisure, Sir Edmund devoted his youth and middle age to field sport and travel in many lands. In the pursuit of big game in four continents his fine marksmanship enabled him to make the very large collection of horned and other trophies now preserved at Leonardslee. He was among the last of British sportsmen to take toll of the dwindling herds of bison in North-west America, and the first European to obtain a specimen of the little desert antelope, named after him, Gazella Loderi, which inhabits the Sahara contentedly without access to water.

Were that all, it would scarcely serve to raise Sir Edmund Loder above the common ruck of biggame shooter and globe-trotter; but he possessed and exercised the gift of accurate observation, enabling him to acquire much sound knowledge of the habits of wild animals, and to distinguish their specific affinities. Unfortunately, he had 